\title{
IUFOST2006/1055
}

\section{Exploring mastication of cellular solids and assessment of mechani- cal behaviour using finite elements calculation}

\author{
S. Guessasma and G. Della Valle
}

INRA Research Unit : Biopolymers, Interactions, Assemblies, rue de la Géraudière, 44000 Nantes, France sofiane.guessasma@nantes.inra.fr

Human mastication of food products is a complex process of particle reduction and hydratasation in which compression and shearing forces evolve. In order to understand chewing mechanism of cereal based products, a preliminary analysis of mechanical behaviour of open cell structures (Roberts and Garboczi 2002) was conducted based on finite element calculation (Topping et al. 2004). Structural effects (Figure 1) were introduced permitting to relate Young's modulus to structural attributes (Gibson and Ashby 1997) under pure compression test conditions. Results show a large effect of structure attributes especially void size and distribution. Coalescence phenomena are also important factors affecting wall thickness dispersion and leading to lower Young's modulus value.

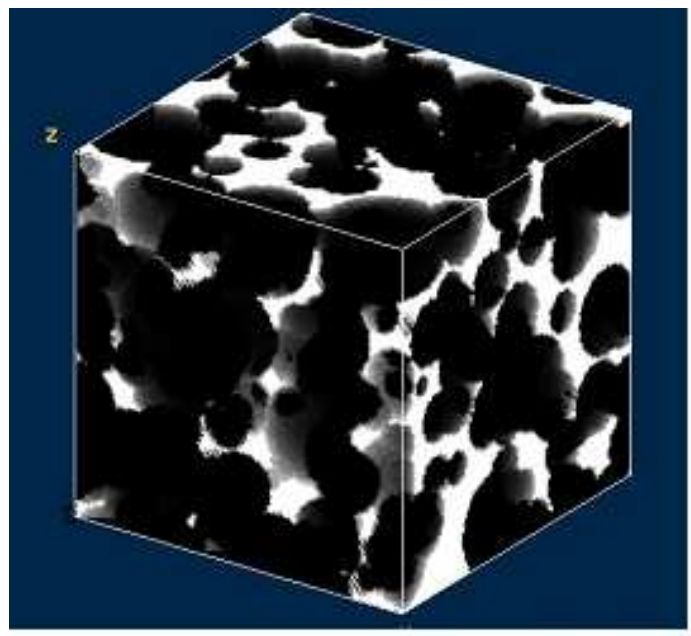

(a)

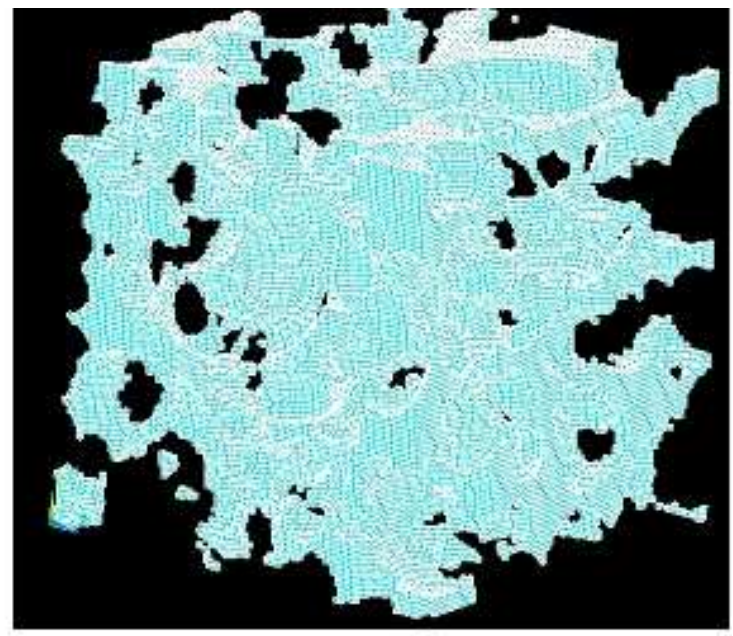

(b)

Figure 1. (a) Typical 3D view of an open cell structure. relative density $=0.1$, bubble distribution size centred around $1 \mathrm{~mm}$. distribution width $\mathrm{s} / \mathrm{r}=0.3$. (b) Regular meshed structure [2] of the open cell solid (left side) containing about 125000 cubic elements.

References.

Gibson, LJ and Ashby, MF (1997), Cellular solids. Cambridge, pergamon Press Ltd, 528 pp.

Roberts, A. P. and E. J. Garboczi (2002). 'Elastic properties of model random three-dimensional open-cell solids. Journal of the Mechanics and Physics of Solids 50(1): 33-55.

Topping, B. H. V., Muylle, J., Putanowicz, R. and Cheng, B. (2004), Finite Element Mesh Generation, Saxe-Coburg Publ., Edinburgh, 272 pp. 